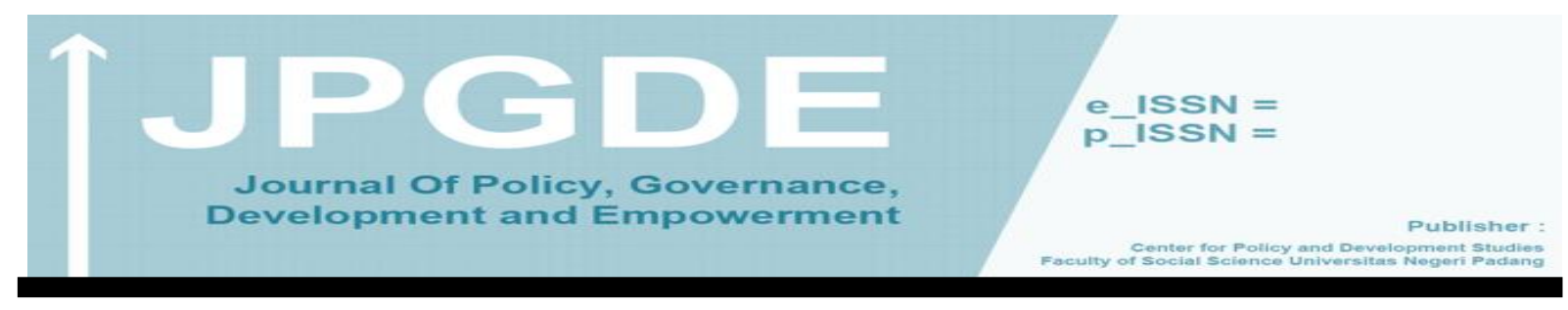

\title{
EFEKTIVITAS PENANGGULANGAN BENCANA KEBAKARAN HUTAN DAN LAHAN DI KABUPATEN SAROLANGUN
}

\author{
(Studi Manajemen Bencana) \\ Najmi Laila \\ Ilmu Administrasi Negara, Fakultas Ilmu Sosial \\ Universitas Negeri Padang \\ Email: najmilaila66@gmail.com
}

\begin{abstract}
Abstrak
Artikel ini bertujuan untuk mendeskripsikan temuan penelitian yang berupa efektivitas penanggulangan bencana kebakaran hutan dan lahan di Kabupaten Sarolangun, peneliti menggambarkan faktor penyebab terjadinya bencana kebakaran hutan dan lahan, kemudian untuk mengetahui efektivitas penanggulangan bencana kebakaran hutan dan lahan di Kabupaten Sarolangun. Hal ini dilakukan berdasarkan pelaksanaan tugas dan fungsi dari intansiinstansi terkait penanggulangan bencana kebakaran hutan dan lahan. Selanjutnya Tujuan penelitian adalah untuk mengetahui proses berlangsungnya dalam efektivitas penanggulangan bencana kebakaran hutan dan lahan. Metode penelitian yang peneliti gunakan adalah penelitian kualitatif yang akan mengggunakan metode deskriptif kemudian teknik penelitian pemilihan informan purposive sampling. Pengumpulan data yang dilakukan dengan cara observasi, wawancara serta studi dokumentasi. Dapat diketahui hasil penelitian ini menunjukkan bahwasanya efektivitas penanggulangan bencana kebakaran hutan dan lahan di Kabupaten Sarolangun masih dianggap belum efektif dikarenakan lokasi kebakaran hutan dan lahan sulit ditempuh.
\end{abstract} dan lahan.

Kata kunci: Efektivitas, Penanggulangan bencana, Kebakaran hutan

\section{Pendahuluan}

Kabupaten Sarolangun memiliki hutan dan lahan yang subur sehingga masyarakat di Kabupaten Sarolangun sebagian besarnya memanfaatkan hal tersebut sebagai lahan lahan perkebunan seperti lahan karet, sawit, persawahan, perkebunan jagung.Akan tetapi pada proses pembukaan lahan tersebut masyarakat lebih memilih proses pembukaan lahan yang instan dan minimnya biaya dengan cara membakar lahan tersebut tanpa pengawasan yang menyebabkan kebakaran hutan dalam skala besar yang berdampak kepada terganggunya aktivitas masyarakat, seperti diliburkan kegiatan belajar 


\section{JPGDE \\ Journal Of Policy, Governance, \\ Development and Empowerment}

mengajar di sekolah, aktivitas di luar ruangan terganggu akibat kabut asap yang semakin meluas, penglihan dengan jarak pandang sangat dekat, cuaca menjadi gersang, udara menjadi tidak sehat, yang tidak hanya dirasakan oleh masyarakat Kabupaten Sarolangun tetapi juga di rasakan oleh daerah-daerah yang ada di sekitar Kabupaten Sarolangun, seperti daerah perbatasan antara Provinsi Jambi dengan Sumatera Selatan, kemudian meningkatnya penderita penyakit ISPA, kerugian ekonomis maupun kerusakan lingkungan.

Dalam hal ini pemerintah Kabupaten Sarolangun menetapkan Peraturan Daerah Kabupaten Sarolangun Nomor 6 Tahun 2017 tentang penanggulangan bencana dalam pasal 3 yang bertujuan untuk: memberikan perlindungan kepada masyarakat dari ancaman bencana, menjamin terselenggaranya penanggulangan bencana secara terencana, terpadu, terkoordinasi dan menyeluruh, menghargai budaya dan kearifan lokal, membangun partisipasi dan kemitraan publik serta swasta, mendorong semangat gotong royong, kesetiakawanan kedermawanan, dan menciptakan perdamaian dalam kehidupan bermasyarakat, berbangsa dan bernegara.

Berdasarkan hal tersebut peneliti melakukan penelitian tentang Efektivitas penanggulangan bencana kebakaran hutan dan lahan di Kabupaten Sarolangun. Efetivitas berasal dari kata efektif yang berarti suatu kegiatan tersebut dikatakan berhasil, dan tepat untuk mengambil tindakan dari suatu kegiatan itu sendiri. Menurut Steers (1997) mengatakan bahwa efektivitas merupakan tujuan dari suatu organisasi yang akan melihat keuntungan dari keseluruhan proses menyampingkan tujuan dari sumberdaya manusianya tersebut. Kemudian menurut Halim (Ely Cintana Dewi, dkk (2014:3) efektivitas adalah suatu kegiatan yang hasilnya sangat besar terhadap tanggung jawab, yang bertujuan berhasilnya suatu kegiatan telah direncanakan. Efektivitas itu sendiri adalah kesanggupan dalam suatu organisasi yang menyesuaikan pada lingkungan kemudian diharapkan berhasil untuk mencapai suatu tujuan. Dari beberapa defenisi sebelumnya dapat peneliti simpulkan bahwasanya efektivitas bisa dikatakan efektif apabila tujuan dari suatu organisasi dapat dikatakan berjalan sesuai dengan yang diharapkan. Dengan ini efektivitas dapat dikatakan bisa menyesuaikan apabila berefek pada hal yang ditimbulkan dari kegiatan yang dilaksanakan. Menurut Muasaroh(Afner Son Wangka, dkk. (2018). Efektivitas dapat dijelaskan bahwa: efektivitas suatu program dapat dilihat dari aspek tugas atau fungsi, yaitu: lembaga dikatakan efektivitas apabila sudah melaksanakan tugas dan fungsinya, dengan begitu suatu program akan efektiv jika tugas dan fungsinya dapat terlaksana dengan baik dan benar.

Konsep Penanggulangan bencana kebakaran hutan dan lahan secara umumnya dapat dikatakan sebagai salah satu usaha untuk menetapkan suatu kebijakan dari pembangunan yang berdampak pada timbulnya bencana, kemudian kegitan pencegahan terhadap bencana, tanggap darurat serta rehabilitasi. 


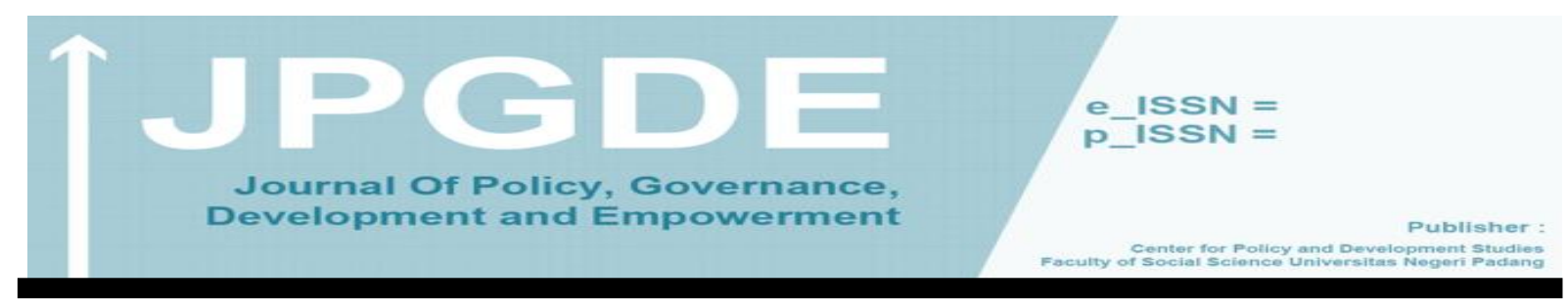

\section{Metode Penelitian}

Jenis penelitian yang peneliti gunakan adalah penelitian kualitatif yang akan mengggunakan metode deskriptif, Penelitian yang berlokasi di Kantor BPBD Kabupaten Sarolangun, Dinas Lingkungan Hidup Kabupaten Sarolangun, Polres Kabupaten Sarolangun, Dinas Pemadam dan Penyelamatan Kabupaten Sarolangun, serta Dinas Daops Manggala Agni Sumatera XIII Kabupaten Sarolangun,kemudian pemilihan informan dalam penelitian ini menggunakan cara purposive sampling. Pengumpulan data yang dilakukan dengan cara observasi, wawancara serta studi dokumentasi.

Uji keabsahan data yang peneliti lakukan dalam penelitian ini menggunakan teknik trigulasi metode dan sumber. Penelitian yang peneliti lakukan dengan cara membandingkan informasi atau data hasil wawancara dengan observasi. Untuk mengetahui dan menjamin keabsahan data, penelti memerlukan teknik pemeriksaan untuk keabsahan data, yang diperiksa adalah data yang didapat selama berada dilapangan.

\section{Hasil dan Pembahasan}

\section{Efektivitas Penanggulangan Bencana Kebakaran Hutan dan Lahan di Kabupaten Sarolangun}

Pada dasarnya penanggulangan bencana dapat diartikan sebagai serangkaian upaya dan usaha demi berlangsungnya kebijakan pembangunan yang mempunyai resiko timbulnya bencana, kebijakan kegiatan pencegahan bencana meliputi tanggap darurat bencana, pemberi bantuan darurat, pemulihan, dan kesiapsiagaan.

Berdasarkan hasil temuan penelitian, peneliti dapat mengetahui bahwasanya kebakaran hutan dan lahan disebabkan oleh 2 faktor yaitu faktor alam dan faktor manusia, kemudian peneliti dapat mengetahui bahwasanya tidak efektifnya penanggulangan bencana kebakaran hutan dan lahan di Kabupaten Sarolangun di sebabkan oleh:

a. Faktor alami

Berdasarkan hasil wawancara yang dilakukan peneliti dengan pihak BPBD dapat diketahui bahwa faktor alami yang dapat menyebabkan kebakaran hutan dan lahan di Kabupaten Sarolangun adalah kemarau yang berkepanjangan sehingga menyebabkan kebakaran terjadi secara tiba-tiba dikarenakan tanaman yang kekeringan sehingga menjadikan hal tersebut bahan bahan bakar yang baik jika terkena percikan api, kemudian sambaran petir pada hutan dan lahan yang kering yang dapat menyebabkan kebakaran hutan dan lahan di Kabupaten Sarolangun.

a.

Faktor manusia 


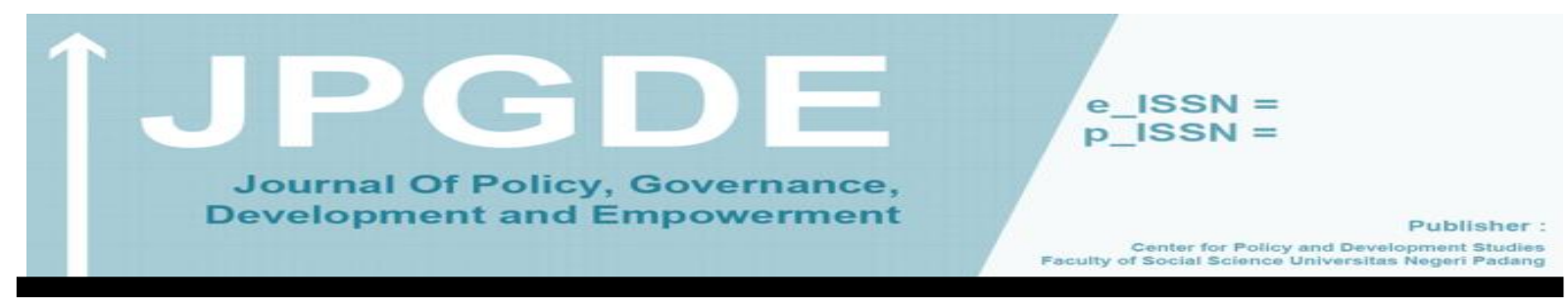

Berdasarkan hasil wawancara yang dilakukan peneliti dengan pihak BPBD dapat diketahui bahwa masyarakat di Kabupaten Sarolangunsebagian besarnyaberprofesi sebagai petani ataupun penggarapmemilih mancangkul dan memupuk dalam bentuk pengolahan lahan. Kegiatan iniakan lebih aman dan tidak merugikan orang lain dalam bentuk pengolahan lahan tersebut. Tetapi pada kenyataannya, masih ada masyarakat yang melakukan dengan cara membakar di lahan perkebunannya, hal ini dilakukan karena masyarakat menganggap cara membakar di lahan perkebunan tersebut membutuhkan waktu yang relatif lebih cepat dan mengeluarkan biaya yang lebih murah.

Berdasarkan faktor tersebut dapat peneliti ketahui efektivitas penanggulangan bencana kebakaran hutan dan lahan di Kabupaten Sarolangun itu tidak efektif disebabkan oleh beberapa hal yaitu: Adapun indikator yang peneliti gunakan untuk Efektivitas penanggulangan bencana kebakaran hutan dan lahan di Kabupaten Sarolangun yaitu indikator yang dikemukakan oleh Muasaroh (2010:13), Efektivitas dapat dijelaskan bahwa suatu program dapat dilihat dari aspek antara lain yaitu:

Aspek tugas atau fungsi, yaitu: lembaga dikatakan efektivitas jika melaksanakan tugas dan fungsinya, begitu juga suatu program akan efektiv jika tugas dan fungsinya dapat dilaksanakan dengan baik.

Pelaksanaan tugas dan fungsi Badan Penanggulangan Bencana Daerah (BPBD) Kabupaten Sarolangun dalam penanggulangan bencana kebakaran hutan dan lahan di Kabupaten Sarolangun yaitu: Adanya pelaksanaan tugas dan fungsi BPBD Kabupaten Sarolangun berdasarkan gugus tugas dalam penanggulangan bencana kebakaran hutan dan lahan di Kabupaten Sarolangun, untuk mengetahui seberapa efektif penanggulangan bencana kebakaran hutan dan lahan. BPBD mempunyai tugas pokok memimpin, mengendalikan dan mengkoordinasikan serta mempertanggungjawabkan kebijakan teknis penyusunan dan pelaksanaan kebijakan daerah yang bersifat spesifik dalam bidang penanggulangan bencana di Kabupaten Sarolangun. Kurang efektifnya penanggulangan bencana kebakaran hutan dan lahan di Kabupaten Sarolangun, dikarenakan banyak faktor penghambat yang mempengaruhi proses penanggulangan kebakaran hutan dan lahan, salah satunya yaitu akses jalan yang kurang mendukung menuju daerah-daerah yang sulit di jangkau, kemudian air sangat sulit didapatkan pada saat musim kemarau yang berkepanjangan, sementara itu titik hotspot atau titik api tidak hanya terdapat di satu tempat melainkan di tempat-tempat lainnya yang terjadi secara bersamaan, maka sering kali cukup sulit penanggulangan bencana kebakaran hutan dan lahan, akan tetapi BPBD berusaha melakukan dan menerapkan tugas dan fungsi yang sudah di tetapkan dalam penanggulangan bencana.

Pelaksanaan tugas dan fungsi Dinas Lingkungan Hidup Kabupaten Sarolangun dalam penanggulangan bencana kebakaran hutan dan lahan di Kabupaten Sarolangun yaitu: Adapun Peraturan Bupati (PERBUP) No. 9. 2018. 
Untuk melaksanakan tugas sebagaimana yang dimaksud pada ayat (1), UPTD Laboratorium mempunyai fungsi yaitu: memimpin, mengawasi, mengkoordinasi pelaksanaan dalam merencanakan, melayani, menjamin kualitas pengujian dari hasil laboratorium lingkungan pada Dinas Lingkungan Hidup Kabupaten Sarolangun, tidak efektifnya penanggulangan bencana kebakaran hutan dan lahan di Kabupaten Sarolangun, yang disebabkan oleh beberapa hal sehingga mengakibatkan terjadinya kendala dalam penanggulangan kebakaran hutan dan lahan, salah satu kendalanya adalah air sangat sulit didapatkan pada saat musim kemarau atau kekeringan sehingga api sangat sulit dipadamkan, kemudian banyaknya lahan gambut yang sangat sulit di padamkan sehingga semakin lama semakin banyak asap dan titik api, kendala selanjutnya adalah lokasi yang cukup jauh dari jangkauan sangat sulit untuk ditempuh sehingga tidak efektifnya penanganan kebakaran hutan dan lahan ini, selain kendala tersebut juga terdapat kendala lain yaitu minimnya peralatan yang digunakan untuk pemadapan api jika terjadi kebakaran hutan dan lahan, hal tersebut juga menjadi salah satu kendala dalam penanggulangan kebakaran hutan dan lahan.

Pelaksanaan tugas dan fungsi Polres Kabupaten Sarolangun, dalam penanggulangan bencana kebakaran hutan dan lahan di Kabupaten Sarolangun yaitu: Adapun pelaksanaan tugas dan fungsi yang sudah ditetapkan Polres Kabupaten Sarolangun adalah memberikan perlindungan, pengayoman dan pelayanan secara mudah, tanggap dan tidak diskriminatif, serta mengembangkan perpolisian masyarakat yang berbasis pada patuh hukum, sebagaimana yang telah dijelaskan sebelumnya polres Kabupaten Sarolangun bermaksud agar masyarakat lebih menyadari dan mematuhi hukum yang berlaku, serta bersikap adil, demi berjalannya proses penanggulangan bencana kebekaran hutan dan lahan di Kabupaten Sarolangun yaitu: kebakaran ini terjadi bukan hanya berdasarkan cuaca melainkan ulah tangan manusianya, orang yang tidak bertanggung jawab melakukan pembakaran hutan dan lahan untuk kepentingan pribadi, pada saat musim kemarau tiba, banyaknya masyarakat yang membuka lahan dengan cara membakar sehingga sangat sulit untuk dikendalikan, dikarenakan titik api yang tidak hanya satu tempat melaikan ada di beberapa bagian, sehingga ini menjadi salah satu faktor yang menyebabkan ketidak efektivan penanggulangan kebakaran hutan lahan, kemudian akses jalan yang cukup sulit untuk dijangkau.

Pelaksanaan tugas dan fungsi Dinas Pemadam Kebakaran dan Penyelamatan Kabupaten Sarolangun dalam penanggulangan bencana kebakaran hutan dan lahan di Kabupaten Sarolangun yaitu: Pelaksanaan tugas dan fungsi di Dinas Pemadam dan Penyelamatan yaitu penyusunan Program Kerja UPT Pemadam Kerja, pelaksanaan penyuluhan bimbingan dan pembinaan kepada masyarakat tentang cara-cara mencegah dan menanggulangan bahaya 


\section{JPEDE \\ Journal Of Policy, Governance, \\ Development and Empowerment}

kebakaran. Sebagimana yang dimaksud dengan tugas dan fungsi yang sudah dijelaskan tersebut yaitu Dinas pemadam kebakaran dan penyelamatan di Kabupaten Sarolangun menerapkan tugas dan fungsi untuk melakukan pembinaan terhadap masyarakat terkait cara mencegah dan menanggulangi kebakaran di Kabupaten Sarolangun. Kemudian penjelasan mengenai efektivitas penanggulangan kebakaran hutan dan lahan di Kabupaten Sarolangun. Berdasarkan kegiatan yang dilakukan dilapangan yaitu memberikan pelayanan terhadap masyarakat yang membutuhkan bantuan, termasuk pengaduan masyarakat Kabupaten Sarolangun jika ada lahan mereka yang terbakar, tim pemadam kebakaran akan bergegas ke lokasi untuk memadamkan api di tempat tersebut. Kegiatan pemadaman tersebut bisa di katakan tidak efektif apabila kebakaran hutan dan dan lahan bukan hanya terjadi di satu tempat melainkan juga terjadi di berbagai tempat secara bersamaan, sedangkan sumberdaya manusianya masih kurang, dan alat-alat yang tersedia sangat terbatas.

Pelaksanaan tugas dan fungsi Daops Manggala Agni Sumatera XIII Kabupaten Sarolangun dalam penanggulangan bencana kebakaran hutan dan lahan di Kabupaten Sarolangun yaitu: Berdasarkan Pelaksanaan tugas dan fungsi di Daops Manggala Agni Sumatera XIII yaitu: melakukan pencegahan kebakaran hutan secara optimal, menitikberatkan pada peningkatan kesadaran semua pihak akan bahaya kebakaran baik terhadap sumberdaya hutan maupun kehidupan masyarakat, bangsa dan Negara. Kemudian sebenarnya ada 3 yang tangani yaitu, pencegahan, penanggulangan dan penanganan pasca kejadian, untuk mengukur efektivitas penanggulangan kebakaran hutan dan lahan di Kabupaten Sarolangun itu sendiri sebenarnya belum efektif, akan tetapi jika dibandingkan dengan kabupaten-kabupaten lain sinerginya sudah jauh lebih baik, bahkan selama 2-3 tahun ini sudah banyak kemajuan, memang pada dasarnya sulit untuk menggabungkan intansi-intansi terkait tersebut, selain itu juga kesulitan untuk sampai lokasi-lokasi yang jauh dari jangkauan, alat-alat yang digunakan juga sangat terbatas.

Masyarakat di Kabupaten Sarolangun juga mengatakan tidak efektifnya penanggulangan bencana kebakaran hutan dan lahan yang terjadi di Kabupaten Sarolangun dikarenakan: Berdasarkan yang terjadi pada saat musim kemarau tahun 2019 lalu, para petani atau masyarakat yang memiliki lahan ini memanfaatkan cuaca dan keadaan untuk membuka lahan mereka, banyak masyarakat yang tidak bertanggung jawab atas perbuatan mereka, sehingga pemerintah kewalahan dalam mengatasi kebakaran hutan dan lahan yang berskala besar, sebelumnya pemerintah juga sudah mengingatkan kepada masyarakat bahwa tidak boleh membakar hutan dan lahan. Hal ini dianggap tidak efektif dalam penanggulangan kebakaran hutan dan lahan, karena lokasi kebakaran hutan tersebut sangat sulit untuk di jangkau, bahkan mobil 


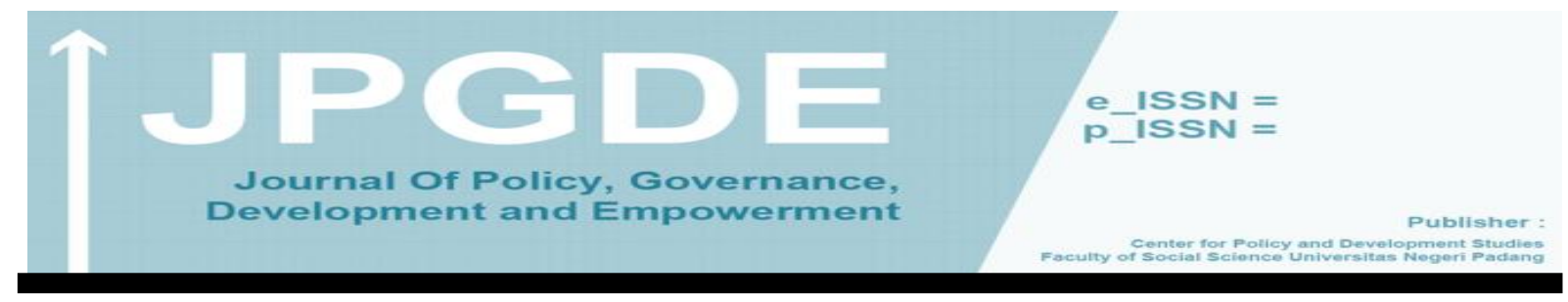

pemadam kebakaran saja tidak bisa sampai ke lokasi kebakaran tersebut, bahkan dalam sehari saja tidak hanya satu masyarakat yang melaporkan kebakaran melainkan banyak di daerah lain.

Dari penjelasan diatas dapat disimpulkan bahwa BPBD, Dinas Lingkungan Hidup, pihak Kepolisian, Dinas Pemadam dan Penyelamatan Kabupaten Sarolangun, Daops Manggala Agni Sumatera XIII menerapkan dan menjalankan tugas dan fungsi masing-masing, hal tersebut diterapkan dan dilaksanakan demi tercapainya penanggulangan bencana kebakaran hutan dan lahan di Kabupaten Sarolangun, kemudian masyarakat di Kabupaten Sarolangun yang ikut terlibat dalam penanganan bencana kebakaran hutan dan lahan di Kabupaten Sarolangun mereka semua sepakat mengatakan bahwa tidak efektifnya penanggulangan bencana kebakaran hutan dan lahan dikarenakan banyaknya kendala, mulai dari sumberdaya manusianya yang kurang, kemudian alat- alat yang digunakan juga sangat minim atau sangat terbatas, kesadaran masyarakatnya akan bahayanya membuka lahan dengan cara membakar itu juga sangat kurang, sehingga mereka terus saja membuka lahan dengan cara yang seperti itu, tanpa memikirkan dampak setelahnya. Pemerintah yang mempunyai tugas dan wewenang masih terus berupaya untuk menanggulangi kebakaran hutan dan lahan di Kabupaten Sarolangun dan terus berusaha semaksimal mungkin dalam penanggulangan kebakaran hutan dan lahan tersebut. Sementara itu tingkat kesadaran masyarakatnya masih minim sekali, masyarakat yang egois hanya mementingkan kepentingan pribadi tanpa memikirkan dampaknya yang dirasakan oleh orang banyak, bukan hanya masyarakat sekitar, tetapi juga masyarakat lainnya sepakat mengatakan bahwa sejauh ini penanggulangan bencana kebakaran hutan dan lahan tidak efektif dikarenakan masih banyak faktor penghambat.

\section{Simpulan}

Dapat disimpulkan bahwasanya instansi-instansi pemerintah sudah menetapkan dan menjalankan tugas dan fungsi serta satuan tugas masingmasing, akan tetapi hal tersebut masih belum dilakukan dengan baik, kemudian tidak efektifnya penanggulangan bencana kebakaran hutan dan lahan di Kabupaten Sarolangun penyebab utama terjadinya kebakaran hutan Kabupaten Sarolangun adalah karena aktivitas manusia dan hanya sebagian kecil yang disebabkan oleh kejadian alam. Kebakaran hutan dapat disebabkan oleh faktorfaktor alam seperti kemarau dan kekeringan. Pada daerah Sub Tropis, seperti Indonesia kebakaran hutan lebih sering terjadi akibat faktor manusia sehingga tidak menutup kemungkinan juga diakibatkan oleh faktor manusia. Kebakaran hutan yang disebabkan oleh faktor manusia melainkan seperti manusia itu sendiri yang membakar lahan dengan sengaja demi kepentingan pribadi, seperti ingin membuka lahan perkebunan baru, kemudian kebakaran yang 


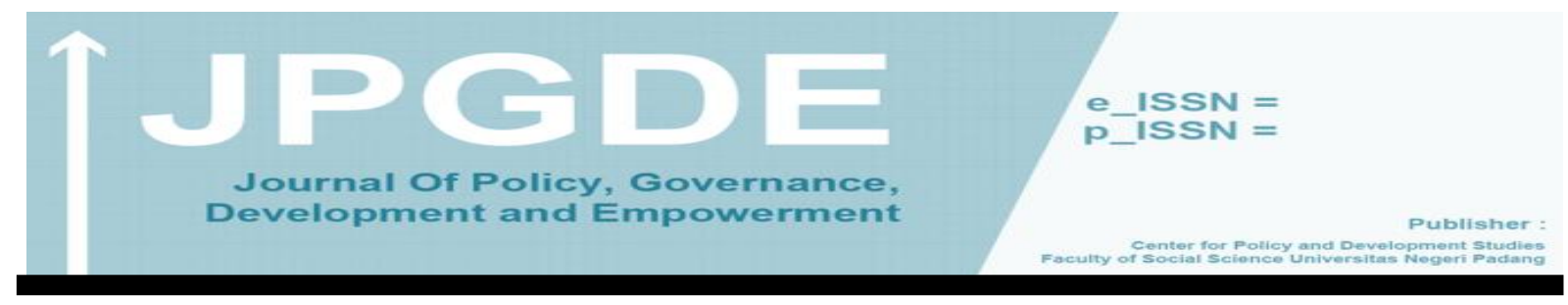

disebabkan oleh faktor alam melainkan seperti, timbulnya petir secara tibatiba, petir dapat timbul tanpa adanya hujan yang diakibatkan oleh cuaca yang sangat ekstrem. Berbeda dengan daerah Tropis, dimana adanya petir selalu diiringi oleh hujan. Sehingga terbakarnya pohon atau tegakan akibat petir tersebut dapat segera padam oleh air hujan. Oleh karena itulah kebakaran hutan akibat faktor alam jarang terjadi di daerah tropis termasuk Indonesia.Sebagian besar masyarakat mengatakan bahwa kebakaran hutan dapat disebabkan oleh akumulasi penumpukan dedaunan atau serasah, panas, petir dan gesekan batuan pada saat memasuki musim kemarau. Berdasarkan informasi tentang kondisi masyarakat tersebut, dapat diketahui bahwa tingkat pengetahuan masyarakat sekitar mengenai faktor penyebab kebakaran masih sangat kurang ataupun minim. Tidak efektifnya penanggulangan kebakaran hutan dan lahan juga di sebabkan oleh faktor lain seperti sulitnya melalui akses menuju lokasi-lokasi kebakaran hutan, kemudian kebakaran hutan dan lahan di Kabupaten Sarolangun pada tahun 2019 juga terjadi dalam skala besar, sehingga pemerintah kesusahan untuk mengatasi kebakaran tersebut.

\section{Daftar Rujukan}

Basrowi dan suwandi. 2008. Memahami penelitian kualitatif. Jakarta: Rineka Cipta.

Edy Sutrisno, M.Si. 2011.Budaya Organisasi. Jakarta: Kencana.

\section{Undang-undang dan Peraturan Daerah}

Undang-undang nomor 24 tahun 2007 tentang penanggulangan bencana.

Undang-Undang Republik Indonesia Nomor 41 tahun 1999, membahas tentang hutan adalah suatu kesatuan ekosistem.

Peraturan Daerah Kabupaten Sarolangun Nomor 6 Tahun 2017 tentang penanggulangan bencana daerah.

Berita Negara Republik Indonesia. 2014. Peraturan Kepala Badan Penanggulangan Bencana. Nomor 4 Tahun 2008. Tentang Pedoman Penyusunan Rencana Penanggulangan Bencana .

Berita Negara Republik Indonesia. 2014. Peraturan Kepala Badan Penanggulangan Bencana. Nomor 12 Tahun 2010. Tentang Pedoman Mekanisme Pemberian Bantuan Perbaikan Perbaikan Darurat. 


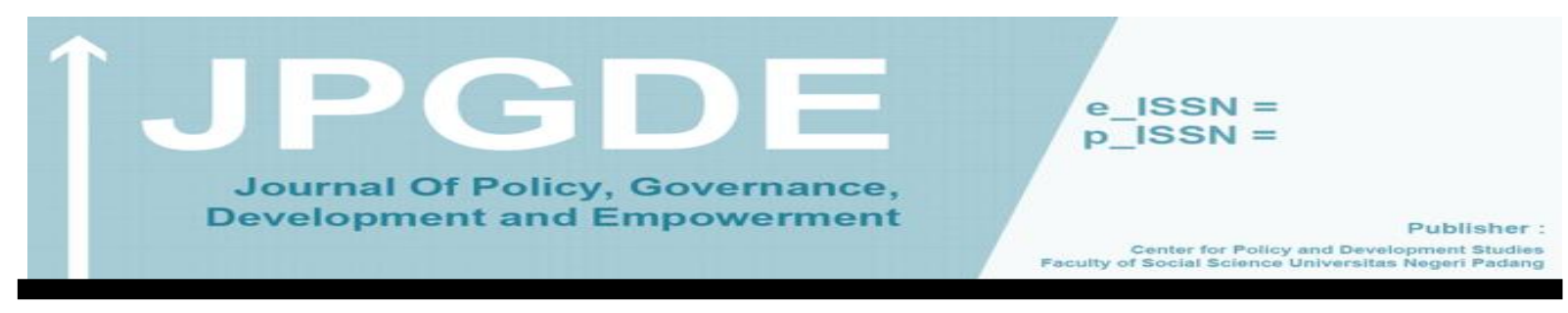

Berita Negara Republik Indonesia. 2014. Peraturan Kepala Badan Penanggulangan Bencana. Nomor 17 Tahun 2010. Tentang Pedoman Umum Penyelenggaraan Rehabilitasi dan Rekontruksi Pasca Bencana.

\section{Jurnal dan Internet}

Afner Son Wangka, dkk. (2018). Efektivitas Penanggulangan Bencana Daerah Dalam Menanggulangi Bencana Banjir Bandung di Kecamatan Tahuna Barat Kabupaten Kepulauan Sangihe. Jurusan Ilmu Pemerintahan, Fakultas Ilmu Sosial dan Ilmu Politik Universitas Islam Ratulangi. Vol.1. No. 1. Tahun 2018.

Ely Cintana, dkk. Analisis Efektivitas Kebijakan Kredit Untuk Meningkatkan Profitabilitas (Studi pada PT. Bank Perkreditan Rakyat Dau Kusumadjaja Malang). Jurnal Administrasi Bisnis (JAB). Vol.17 No. 2 Desember 2014.

Hanawan Desri. 2016. Menyelesaikan Kebakaran Hutan dan Lahan (karhutla) di Indonesia melalui Jalan Pantas atau Jalan Pintas.Seminar Nasional Hukum.Vol 2. No 1. Fakultas Hukum, Universitas Negeri Semarang

Ivan Chofyan, Rahajeng Kusumaningtyas. 2010. Pengelolaan Hutan Dalam Mengatasi Alih Fungsi Lahan Hutan Di Wilayah Kabupaten Subang. Program Studi Perencanaan Wilayah dan Kota, Fakultas Teknik, Universitas Islam Bandung.Vol 13. No 2. 